\title{
Antifungal activities of Punica granatum L. peel-compost tea for controlling damping-off disease caused by $R$. solani
}

Mona, M. Abou El Nour ${ }^{1}$, Zeinab, M.H. Kheiralla ${ }^{2}$, Abdel-Wahab, A.F.M. ${ }^{3}$, Ehab, A.D. Sarhan ${ }^{4}$, Mona, J.M.Wadi ${ }^{5}$

${ }^{1,2}$ Botany Dept., Women's College for Arts, Science and Education, Ain Shams University

${ }^{3}$ Agric. Microbiol. Dept., Soils, Water and Environ. Res. Inst., ARC, Giza, Egypt

${ }^{4}$ Plant Pathology Research Institute, Agricultural Research Center, Giza, Egypt

${ }^{5}$ Biology Dept., Faculty of Science, Al-Azhar University-Gaza, Palestine

Abstract

Rhizoctonia solani is common fungal pathogen to lupine plants (Lupinus albus L.) causing damping-off disease resulting in serious economic losses. In vitro experiment was conducted to evaluate the efficacy of individual compost tea and pomegranate peel-compost tea prepared using water and alkaline water against $R$. solani. Three pomegranate types (two Palestinian and one Egyptian) were used. Greenhouse experiment was also conducted using the Palestinian sour pomegranate peel which showed a significant antifungal activity. Lupine plants were treated with compost alone or combined with pomegranate peel powder and their extracts to control lupine damping-off disease in comparison with untreated infected soil (control), and the fungicide (Rizolex-T). In vitro experiment, results showed that pomegranate peel-compost tea significantly decreased linear growth of the $R$. solani compared to individual compost tea. Alkaline water led to a significant reduction in the fungal growth compared to water. Under greenhouse conditions, all applied treatments significantly induced reduction in the damping-off percentage and improved the nodulation status and growth parameters compared to infested control. The maximum survived plants percentage and growth parameters of lupine plants were recorded for pomegranate peel-compost tea treatment, followed by the fungicide. Whereas the best nodulation status was achieved by the fungicide and pomegranate peel-compost tea. It could be concluded that pomegranate peel-compost tea may provide a high efficacy to pomegranate peel and compost in combination, so it might be used in a commercial scale for controlling damping-off disease.

Keywords: Lupine, $R$. solani, compost, compost tea, pomegranate peels, Rizolex-T.

Corresponding author email: mona_wadi@yahoo.com 


\section{Introduction}

White lupine (Lupinus albus L.) belongs to the leguminous family which has been cultivated in Egypt for human and animal nutrition, also for medical and industrial purposes as well as its efficiency in nitrogen fixation and its improvement to the traditional cereal rotation and protein supply in low input farming systems. In Egypt, Damping-off and root rot diseases are among the most destructive diseases attacking lupine. $R$. solani is proved to be one of the most dominate pathogenic fungi to lupine plants causing root rot symptoms. Some chemicals are effective in controlling plant diseases but they are expensive and not environmentally friendly, therefore, alternative control methods are needed (Abd El-Hai et al., 2016).

Natural products such as the plant-derived ones, e.g. plant extracts and essential oils have recently acquired a great scientific interest as a method of biological control. An increasing number of studies are developed for investigation of the antimicrobial effects of medicinal plants for plant disease control (Manasi et al., 2014).

Pomegranate (Punica granatum L.) is a fruit native to the Middle East, belonging to the Punicaceae family. Pomegranate fruits peel is an inedible part and generally treated as wastes. Pomegranate peel is a rich source of tannins, flavonoids, polyphenols and some anthocyanins. Considerable amount of solid wastes in the form of peels and seeds are generated by the fruit processing industries, and these wastes if not disposed correctly are seen to cause serious environmental problems such as water pollution, unpleasant odors, and greenhouse gas emissions (Soma and Prashanth, 2014).

It was proved by Al-Askar (2012) that the ethanolic extract of pomegranate rinds had different degrees of antifungal activity against Alternaria alternata, Fusarium oxysporum, Phoma destructiva, R. solani, and Sclerotium rolfsii in vitro. Mohamad and Khalil (2015) demonstrated that application of pomegranate peel powder as seed treatment or soil treatment deceased pre and post emergence damping off caused by $F$. oxysporum, compared with untreated infected control under greenhouse conditions.

Some investigations have demonstrated the effectiveness of composts of various origins in suppressing soil-borne plant pathogens, and their application to soil has been proposed to control many different diseases (Borrero et al., 2004 \& Abdollahzadeh et al., 2011). 
Compost tea is obtained by the infusion of compost in water for a period of time, the compost is removed and the remaining solution is the compost tea (Scheuerell and Mahaffee, 2002), compost tea may be one of promised applications of compost.

Compost teas and herbal teas (plant-based extracts) are tools that can be made on the farm to enhance crop fertility and to inoculate the phyllosphere and rhizosphere with soluble nutrients, beneficial microbes, and the beneficial metabolites of microbes (Mokhtar and El-Mougy, 2014). Therefore, the present study was undertaken in vitro as well as in pot experiment to assess the efficiency of compost individually or in combination with pomegranate peel powder and their extracts for suppression of lupine damping-off caused by $R$. solani.

\section{Materials and Methods}

\subsection{Pomegranate peels}

Three different types of commercial pomegranate including two Palestinian (sweet and sour) and one Egyptian (sweet) were used. Palestainian pomegranate fruits were collected from commercial markets in Gaza Strip while the Egyptian type was collected from commercial markets in Cairo. Fresh fruits of pomegranate (Punica granatum L.) were manually peeled. Peels were cut into smaller pieces and washed with tap water followed by distilled water. The peel pieces were air dried enough, then oven dried at $50 \pm 2^{\circ} \mathrm{C}$ for $3-4$ days, and ground using a mechanical grinder (Khan and Hanee 2011).

\subsection{Compost}

Mature compost was kindly provided from Ismailia Agriculture Research Station, Ismailia Governorate, Egypt. Compost was prepared from rice straw, farmyard manure, bentonite, rock phosphate, feldspar, urea, and elemental sulfur and vinasse solution according to (Abdel-Wahab, 2008)

\subsection{Organisms used}

a. Rhizoctonia solani Kühn was kindly provided by legume and forage diseases research department, Plant Pathology Research Institute, ARC, Giza, Egypt which was isolated from naturally infected lupine plants showing damping off symptoms. The fungus was regularly subcultured and maintained on PDA medium (Atlas, 2010) in a refrigerator at $5 \pm 1^{\circ} \mathrm{C}$.

b. Rhizobium (Bradyrhizobium lupini, ARC 408) inoculum was kindly provided by Biofertilizer Production Unit. Soils, Water and Environment Res. Inst., Agric.Res. Center, Giza, Egypt. 


\subsection{Lupine seeds}

Lupine seeds cultivar (Giza 2) were obtained from Legume Crop Res. Dep., Field Crop Res. Inst., Agric. Res. Center, Giza, Egypt.

\subsection{Preparation of compost tea}

Compost tea was prepared according to (Ingham, 2005). The following ingredients (g) were added to one liter tap water:

Mature compost, 143 (compost to water ratio was 1:7); $\left(\mathrm{NH}_{4}\right)_{2} \mathrm{SO}_{4}, 4.5 ; \mathrm{KH}_{2} \mathrm{PO}_{4}, 0.5 ; \mathrm{MgSO}_{4}$ $7 \mathrm{H}_{2} \mathrm{O}, 0.25 ; \mathrm{NaCl}, 0.1$; sucrose, 10 and $\mathrm{MnSO}_{4} 1 \mathrm{H}_{2} \mathrm{O}, 0.2$.

Air was bubbled through the mixture using aquarium pump for five days. Then the liquid mixture was filtered through a 100 mesh screen to remove solid particles.

Alkaline compost tea was prepared by adding the previous ingredients to alkaline water $(0.1 \mathrm{M} \mathrm{KOH} / \mathrm{L})$. Potassium hydroxide has been used to obtain humic extract from composts, and it produces high humic acid yield and contains high amount of K, so it is the preferred choice as an extracting agent (Charest $\boldsymbol{e t}$ al., 2005).

\subsection{Preparation of pomegranate peel-compost tea}

Pomegranate peel-compost tea was prepared by adding the pomegranate peel powder (the three tested types) to compost at ratio 5:100. Alkaline pomegranate peel-compost tea was also prepared.

\subsection{Analytical methods}

Physical characters were detected according to Iglesias-Jimenez and Perez-Garcia (1989). Chemical and microbiological properties were determined according to Page $\boldsymbol{e t}$ al. (1982). Seed germination test was assayed using cress seeds (Lepidium staivum L.) to evaluate compost maturity (Pare et al., 1997). Extinction coefficient $\left(\mathrm{E}_{4} / \mathrm{E}_{6}\right.$ ratio) was measured according to Page et al. (1982) where $E_{4}$ and $E_{6}$ are the optical densities at 465 and $665 \mathrm{~nm}$ wavelengths, respectively. Total phenolics were determined by the method of Singleton and Rossi (1965). Anthocyanins was estimated according to Ranganna (1977). Tannins were assayed according to Earp et al. (1981). Analyses of pomegranate peel powder, compost, compost tea and Palestinian sour pomegranate peel-compost tea assayed at Soils, Water and Environmental Res. Inst. Agric. Res. Center, Giza, Egypt, are summarized in Table (1) and (2). 
Table (1): Analysis of pomegranate peel powder

\begin{tabular}{|l|l|l|l|}
\hline Analysis & $\begin{array}{l}\text { Sour Palestinian } \\
\text { type }\end{array}$ & $\begin{array}{l}\text { Sweet Palestinian } \\
\text { type }\end{array}$ & $\begin{array}{l}\text { Sweet Egyptian } \\
\text { type }\end{array}$ \\
\hline PH & 3.73 & 3.39 & 3.45 \\
\hline EC $(\mathrm{ds} / \mathrm{m})$ & 3.82 & 4.27 & 3.8 \\
Total nitrogen $(\%)$ & 0.62 & 0.77 & 0.74 \\
\hline Organic matter $(\%)$ & 93.35 & 95.21 & 92.16 \\
\hline Organic carbon $(\%)$ & 54.14 & 55.22 & 53.45 \\
\hline Total phosphorus $(\%)$ & 0.23 & 0.21 & 0.33 \\
\hline Total potassium $(\%)$ & 0.84 & 0.91 & 1.02 \\
\hline Total iron $(\%)$ & 0.12 & 0.1 & 0.45 \\
\hline Total manganese $(\mathrm{mg} / 1 \mathrm{~kg})$ & 28.4 & 13.4 & 61.4 \\
Total zinc $(\mathrm{mg} / \mathrm{kg})$ & 15.4 & 11.6 & 21.0 \\
\hline Total copper $(\mathrm{mg} / 1 \mathrm{~kg})$ & 9.4 & 4.8 & 14.6 \\
\hline Total polyphenol $(\mathrm{mg} / \mathrm{g})$ & 154.0 & 125.2 & 82.9 \\
\hline Anthocyanins $(\mathrm{mg} / 100 \mathrm{~g})$ & 601.07 & 1016.1 & 1101.9 \\
\hline Tannins $(\mathrm{mg} / \mathrm{g})$ & 1.3 & 2.86 & 3.64 \\
\hline
\end{tabular}

Table (2): The main characteristics of compost, compost tea and pomegranate peel-compost tea

\begin{tabular}{|c|c|c|c|c|c|}
\hline \multirow[t]{2}{*}{ Parameter } & \multirow[t]{2}{*}{ Compost } & \multicolumn{2}{|c|}{ Compost tea } & \multicolumn{2}{|c|}{$\begin{array}{l}\text { Pomegranate peel- } \\
\text { compost tea }\end{array}$} \\
\hline & & Water & $\begin{array}{l}\text { Alkaline } \\
\text { water }\end{array}$ & Water & $\begin{array}{l}\text { Alkaline } \\
\text { water }\end{array}$ \\
\hline Water holding capacity (\%) & 141.50 & - & - & - & - \\
\hline Bulk density $\left(\mathrm{Kg} / \mathrm{cm}^{3}\right)$ & 0.60 & - & - & - & - \\
\hline $\mathrm{pH}$ & 6.79 & 7.43 & 8.57 & 6.41 & 7.75 \\
\hline $\mathrm{EC}(\mathrm{ds} / \mathrm{m})$ & 5.53 & 8.63 & 11.22 & 8.31 & 11.62 \\
\hline Organic carbon $(\%)$ & 23.60 & 0.06 & 0.13 & 0.51 & 1.02 \\
\hline Organic matter $(\%)$ & 40.59 & 0.10 & 0.23 & 0.88 & 1.76 \\
\hline Total N (\%) & 1.42 & 0.07 & 0.04 & 0.07 & 0.07 \\
\hline Total - P (\%) & 0.46 & - & - & - & - \\
\hline Total - K $(\%)$ & 1.60 & - & - & - & - \\
\hline $\mathrm{NH}_{4}(\mathrm{ppm})$ & 441.0 & 469 & 587 & 496 & 661 \\
\hline $\mathrm{NO}_{3}(\mathrm{ppm})$ & 371.0 & 30 & 42 & 30 & 41 \\
\hline Available P (ppm) & 311.0 & 40 & 54 & 60 & 78 \\
\hline Available K (ppm) & 613.5 & 257 & 400 & 320 & 460 \\
\hline $\mathrm{E}_{4} / \mathrm{E}_{6}$ & 2.54 & 1.547 & 2.038 & 1.924 & 2.253 \\
\hline Germination index for cress (\%) & 79.5 & 90 & 93 & 91 & 94 \\
\hline Germination index for barley (\%) & 89.7 & - & - & - & - \\
\hline Humic carbon/fulvic carbon & 2.11 & - & - & - & - \\
\hline Humification index (\%) & 1.42 & - & - & - & - \\
\hline Humification rate (\%) & 19.0 & - & - & - & - \\
\hline $\mathrm{CO}_{2}$-evolution $(\mathrm{mg} / \mathrm{g})$ & 5.32 & - & - & - & - \\
\hline $\begin{array}{l}\text { Dehydrogenase activity (mg TPF*/100g } \\
\text { or ml./24hr) }\end{array}$ & 89.8 & 93.548 & 100.324 & 95.838 & 118.614 \\
\hline Total count of bacteria (cfu/g or ml) & $3.2 \times 10^{7}$ & $1.8 \times 10^{7}$ & $7 \times 10^{7}$ & $1.7 \times 10^{7}$ & $12 \times 10^{7}$ \\
\hline Total count of fungi (cfu/g or ml) & $1.1 \times 10^{5}$ & $1 \times 10^{5}$ & $4.3 \times 10^{5}$ & $0.7 \times 10^{5}$ & $1.1 \times 10^{5}$ \\
\hline $\begin{array}{l}\text { Total count of actinomycetes (cfu/g or } \\
\mathrm{ml} \text { ) }\end{array}$ & $1.5 \times 10^{6}$ & $1.2 \times 10^{5}$ & $4 \times 10^{5}$ & $0.8 \times 10^{5}$ & $2 \times 10^{5}$ \\
\hline
\end{tabular}

Tri-Phenyl-Formazan.* 


\subsection{Antifungal effect of compost tea and pomegranate peel-compost tea on linear growth of $R$. solani}

The antifungal effect was studied in vitro by a poisoned food technique (Agarwal $\boldsymbol{e t}$ al., 2001). One $\mathrm{ml}$ of each of the different teas was added to $45-40^{\circ} \mathrm{C}$ cooled sterilized PDA medium $(100 \mathrm{ml})$ and shaken thoroughly. The medium was then poured into $9 \mathrm{~cm}$ diameter Petri dishes (three replicates), and untreated PDA medium was used as control. Five mm diameter disc of the

fungus (one-week-old culture) was placed at the center of each of the poured plates. Plates were incubated at $25 \pm 2^{\circ} \mathrm{C}$ until the fungal growth in the control dishes was completed. Percentage of inhibition was calculated due to the treatments against control using the following formula (Whitehead, 1957):

$$
\text { Percentage inhibition }=\frac{\mathrm{C}-\mathrm{T}}{\mathrm{C}} \times 100
$$

Where $\mathrm{C}$ is the average of three replicates of hyphal extension $(\mathrm{mm})$ of control, and $\mathrm{T}$ is the average of three replicates of hyphal extension $(\mathrm{mm})$ of plates treated with tested material.

\subsection{Greenhouse experiment}

The greenhouse experiment was carried out at Agric. Res. Centre, Giza, Egypt, during winter season of 2015/2016. Soil was sterilized with $5 \%$ formalin solution and left to dry before use. Each Pot (25cm in diameter) was filled with $5 \mathrm{Kg}$ of the sterilized soil.

\subsubsection{Preparation of fungal inoculum}

Fungal inoculum was prepared according to (Harborne, 2005) as follow. Sorghum grains -sand mixture $(3: 1 \mathrm{w} / \mathrm{w})$ in $500 \mathrm{ml}$ glass bottles was autoclaved at $121^{\circ} \mathrm{C}$ for 30 minutes. The sterilized bottles were inoculated with discs $(5 \mathrm{~mm})$ of 7 days old culture of $R$. solani and incubated at $25 \pm 2^{\circ} \mathrm{C}$ for 15 days. Fungal inoculum was mixed thoroughly with the potted sterilized soil at the rate of $4 \%$ inoculum level $(w / w)$, uninoculated pots were left as control. The potted soil was adequately watered for one week to enhance growth and distribution of the fungal inoculum.

\subsubsection{Treatments}

Treatments were as follow: compost, compost with Palestinian sour pomegranate peel powder, compost tea with alkaline water, Palestinian sour pomegranate peel-compost tea with alkaline water, aqueous extract of Palestinian sour pomegranate peel powder, and the fungicide 
(Rizolex-T), untreated pots (infested and non infested) were left as control. The treatments were arranged in a complete randomized design with three replicates.

\subsubsection{Seed treatment}

Lupine seeds were soaked in compost tea, pomegranate peel-compost tea and aqueous extract of pomegranate peel powder for two hours before sowing. For the other treatments and untreated control, lupine seeds were soaked in sterilized water for two hours before sowing. Set of lupine seeds was treated with Arabic gum (1\%) as sticker and then the commercial fungicide Rizolex-T at the recommended dose ( $3 \mathrm{~g} / \mathrm{kg}$ seeds). Five pre-treated lupine seeds were sown into each pot.

\subsubsection{Soil treatment}

Rhizobium inoculum was added during sowing to potted soils at rate of $600 \mathrm{~g}$ inoculum/fed. Compost and compost with Palestinian sour pomegranate peel powder were added to the potted soil at the rate of 4000 and $200 \mathrm{Kg} / \mathrm{fed}$, respectively. Compost tea with alkaline water, Palestinian sour pomegranate peel-compost tea with alkaline water and aqueous extract of Palestinian sour pomegranate peel powder were applied as soil drench twice at 20 days intervals at rate of $75 \mathrm{~L} / \mathrm{fed}$.

\subsubsection{Disease assessment}

Disease incidence was determined by recording the percentage of pre-emergence damping-off (unmerged seeds) 15 days after sowing as well as percentage of post-emergence damping-off (dead seedlings) and the survived plants 55 days after sowing.

\subsubsection{Plant measurements}

Plants were uprooted at harvest 75 days of sowing to estimate plant components i.e., plant height $(\mathrm{cm})$, dry weight of shoot and root (g/plant), chlorophyll content of leaves $(\mathrm{mg} / \mathrm{g})$, and nodulation status i.e., number of nodules/plant, dry weight of nodules per plant (mg/plant) and nitrogenase activity ( $\mu$ mole/plant/hr.). Chlorophyll content was measured at optical density 650 and $665 \mathrm{~nm}$ (Arnon, 1949). The nitrogenase activity of mature roots nodules was estimated according to Hardy et al. (1973).

\subsection{Statistical analysis}

The obtained data were subjected to an analysis of variance (ANOVA) according to the procedure of (Gomez and Gomez, 1984). 


\section{Results}

\subsection{Antifungal activity of compost tea and pomegranate peel-compost tea.}

As shown in Table 3, all the prepared compost tea and pomegranate peel-compost tea using water or alkaline water inhibited the linear growth of $R$. solani with different degrees, except the prepared compost tea with water had no effect.

It was found that the prepared compost teas using alkaline water strongly exhibited more antifungal effect $(63.50 \%)$ than those prepared using water $(26.25 \%)$.

Results of antifungal effect of the chosen pomegranate types proved that the Palestinian sour pomegranate had the best result. The extraction by alkaline water demonstrated the strongest inhibitory effect compared to water. Accordingly, the Palestinian type was chosen, also compost tea and pomegranate peel-compost tea will be prepared by alkaline water to perform the next experiment (greenhouse).

Table (3): Antifungal effect of compost tea and pomegranate peel-compost tea on linear growth of $R$. solani

\begin{tabular}{|l|c|c|}
\hline \multicolumn{1}{|c|}{ Parameters } & \multicolumn{2}{|c|}{ \% Inhibition } \\
\hline Extracts & Water & Alkaline water \\
\hline Compost tea & 0.00 & 64.00 \\
\hline $\begin{array}{l}\text { Palestinian sour pomegranate } \\
\text { peel-compost tea }\end{array}$ & 45.33 & 60.00 \\
\hline $\begin{array}{l}\text { Palestinian sweet pomegranate } \\
\text { peel-compost tea }\end{array}$ & 34.00 & 60.00 \\
\hline $\begin{array}{l}\text { Egyptian sweet pomegranate } \\
\text { peel-compost tea } \\
\text { Mean }\end{array}$ & 25.67 & 63.50 \\
\hline
\end{tabular}

LSD at 0.05: $\quad$ Solvent $=0.96$

Solvent $\mathbf{x}$ Extract $=1.95$

\subsection{Effect of compost alone or combined with pomegranate peel powder and their extracts} on lupine plants under greenhouse conditions.

\subsubsection{Damping-off}

Results illustrated in Table 4 show that all treatments significantly decreased the percentage of pre- and post-emergence damping-off and increased the percentage of survived plants compared to untreated infested soil (control).

Pomegranate peel-compost tea treatment significantly exhibited lower percentage of pre emergence damping-off (29.00\%) and higher percentage of survived plants (67.00\%) with no 
significant difference in percentage of post-emergence damping-off compared to the fungicide Rizolex-T (Table 4).

Compost with pomegranate peel powder significantly increased the percentage of survived plants (35\%) compared to compost singly (30\%). Furthermore pomegranate peelcompost tea significantly increased the percentage of survived plants (67\%) compared to compost tea singly $(45 \%)$.

The pomegranate peel-compost tea showed a significant high percentage of survived plants compared to combination of compost with pomegranate peel powder (Table 4).

Table (4). Effect of compost alone or combined with pomegranate peel powder and their extracts on percentage of damping off disease of lupine plants.

\begin{tabular}{|l|c|c|c|}
\hline \multirow{2}{*}{ Preatments } & \multicolumn{2}{|c|}{ Incidence of damping-off (\%) } & \multirow{2}{*}{ Survived plants (\%) } \\
\cline { 2 - 4 } & Pre-emergence & 1.00 & 95.00 \\
\hline Non infested soil (Control) & 4.00 & 15.00 & 5.00 \\
\hline Infested soil (Control) & 80.00 & 5.00 & 30.00 \\
\hline Compost & 65.00 & 8.00 & 35.00 \\
\hline $\begin{array}{l}\text { Compost with pomegranate peel } \\
\text { powder }\end{array}$ & 57.00 & 9.67 & 45.00 \\
\hline Compost tea & 45.33 & 4.00 & 67.00 \\
\hline Pomegranate peel-compost tea & 29.00 & 14.00 & 49.33 \\
\hline $\begin{array}{l}\text { Aqueous extract of pomegranate } \\
\text { peel }\end{array}$ & 36.67 & 4.33 & $\mathbf{2}$ \\
\hline The fungicide (Rizolex-T) & 31.67 & $\mathbf{1 . 7 6}$ & $\mathbf{1 . 8 2}$ \\
\hline LSD 0.05 & $\mathbf{2 . 3 1}$ & & \\
\hline
\end{tabular}

\subsubsection{Nodulation status}

As can be seen from Table 5, all treatments significantly improved the nodulation status of lupine plants compared to untreated infested and non infested soil (control). Rizolex-T had the highest number of nodules/plant (13.67), dry weight of nodules (278 mg/plant), and nitrogenase activity $(9.17 \mu \mathrm{mole} / \mathrm{plant} / \mathrm{hr}$.) followed by pomegranate peel-compost tea $(12.67,253.00$, and 9.11, respectively).

Compost with pomegranate peel powder and pomegranate peel-compost tea significantly improved the nodulation status of plant compared to compost and compost tea alone. Also, the 
combined treatment as liquid (pomegranate peel-compost tea) led to a significant increasing in nodules dry weight $(253 \mathrm{mg} / \mathrm{plant})$ and nitrogenase activity $(9.11 \mu \mathrm{mole} / \mathrm{plant} / \mathrm{hr}$.) compared to combination of solid compost with pomegranate peel powder $(227.67 \mathrm{mg} / \mathrm{plant}$, and 8.22 $\mu$ mole/plant/hr., respectively).

Table (5): Effect of compost alone or combined with pomegranate peel powder and their extracts on nodulation status of lupine plants.

\begin{tabular}{|l|c|c|c|}
\hline \multicolumn{1}{|c|}{ Parameters } & $\begin{array}{l}\text { No. of } \\
\text { nodules/plant }\end{array}$ & $\begin{array}{l}\text { Dry weight of } \\
\text { nodules (mg/plant) }\end{array}$ & $\begin{array}{l}\text { Nitrogenase activity } \\
(\mu \text { mole/plant/hr. }\end{array}$ \\
\hline Non infested soil (Control) & 7.67 & 107.00 & 1.67 \\
\hline Infested soil (Control ) & 2.67 & 62.67 & 7.30 \\
\hline Compost & 11.00 & 208.00 & 8.22 \\
\hline Compost with pomegranate peel powder & 13.00 & 227.67 & 4.68 \\
\hline Compost tea & 9.00 & 166.67 & 9.11 \\
\hline Pomegranate peel-compost tea & 12.67 & 253.00 & 5.66 \\
\hline Aqueous extract of pomegranate peel & 12.67 & 245.00 & 9.17 \\
\hline The fungicide (Rizolex-T) & 13.67 & 278.00 & $\mathbf{0 . 5 2}$ \\
\hline LSD 0.05 & $\mathbf{2 . 7 2}$ & $\mathbf{1 7 . 1 7}$ & \\
\hline
\end{tabular}

\subsubsection{Growth parameters}

All growth parameters studied were significantly improved with the applied treatments compared to untreated infested and non infested soil (control). The highest values of plant height, shoot dry weight, root dry weight and chlorophyll content of leaves were achieved with pomegranate peel-compost tea $(39.00,2.60,1.36$ and 3.30 , respectively) followed by the fungicide (37.67, 2.40, 0.93 and 3.00, respectively).

Application of combination of compost with pomegranate peel powder and pomegranate peel-compost tea significantly improved growth parameters of lupine plants compared to compost and compost tea singly. Furthermore, a significant difference was observed in shoot and root dry weight of lupine plants treated with pomegranate peel-compost tea compared to combination of compost with pomegranate peel powder (Table 6). The combination of compost with pomegranate peel powder exhibited a significant improvement for some growth parameters compared to Rizolex-T. 
Table (6): Effect of compost alone or combined with pomegranate peel powder and their extracts some growth parameters of lupine plants.

\begin{tabular}{|l|c|c|c|c|}
\hline \multicolumn{1}{|c|}{ Parameters } & $\begin{array}{l}\text { Plant } \\
\text { height } \\
\text { (cm) }\end{array}$ & $\begin{array}{l}\text { Shoot dry } \\
\text { weight } \\
\text { (g/plant) }\end{array}$ & $\begin{array}{l}\text { Root dry } \\
\text { weight } \\
\text { (g/plant) }\end{array}$ & $\begin{array}{l}\text { Chlorophyll } \\
\text { content of leaves } \\
\text { (mg/g) }\end{array}$ \\
\hline Non infested soil (Control) & 28.33 & 1.20 & 0.57 & 2.50 \\
\hline Infested soil (Control) & 25.67 & 0.90 & 0.40 & 2.40 \\
\hline Compost & 37.00 & 1.70 & 0.88 & 2.80 \\
\hline $\begin{array}{l}\text { Compost with pomegranate } \\
\text { peel powder }\end{array}$ & 37.67 & 2.07 & 1.18 & 3.33 \\
\hline Compost tea & 30.33 & 1.50 & 0.79 & 3.00 \\
\hline $\begin{array}{l}\text { Pomegranate peel-compost } \\
\text { tea }\end{array}$ & 39.00 & 2.60 & 1.36 & 3.30 \\
\hline $\begin{array}{l}\text { Aqueous extract of } \\
\text { pomegranate peel }\end{array}$ & 32.33 & 1.60 & 0.85 & 3.07 \\
\hline The fungicide (Rizolex-T) & 37.67 & 2.40 & 0.93 & 3.00 \\
\hline \multicolumn{1}{|c|}{ LSD 0.05 } & $\mathbf{3 . 0 5}$ & $\mathbf{0 . 2 1}$ & $\mathbf{0 . 1 0}$ & $\mathbf{0 . 2 7}$ \\
\hline
\end{tabular}

\section{Discussion}

Since no alternative to chemical control alone is effective as fungicides in reducing plant diseases, promising alternatives of biological control with natural compost and plant extracts treatments were tested to develop a satisfactory control strategy of plant diseases. In this regard, certain strategies, such as adding calcium salts, carbohydrates, amino acids, and other nitrogen compounds to bio-control treatments in order to enhance bio-control activity of antagonists against fungal pathogens, were suggested (Janisiewicz et al., 1998). Therefore, the present study was designed to investigate the efficacy of combining agricultural wastes (pomegranate peel) with compost against the fungal pathogen $R$. solani.

The prepared compost tea and pomegranate peel-compost tea using water or alkaline water inhibited the linear growth of $R$. solani with different degrees. Results are in agreement with some previous studies which showed that compost teas inhibited the mycelial growth of numerous plant pathogens (Scheuerell and Mahaffee, 2002 and 2006). The suppressive effect on linear growth of the tested pathogens shown by compost extracts is a combination of various factors, such as competition for nutrients, antibiosis, and production of lytic enzymes outside the cells, which are capable of degrading the fungus wall (Scheuerell and Mahaffee, 2002). 
As revealed in this study, pomegranate peel-compost tea significantly showed higher antifungal effect than individual compost tea. This may be attributed to the nutritive value of pomegranate peel which improved the quality of compost tea. These results were supported by Naidu et al. (2010) who found that addition of microbial food sources such as sugar or molasses, kelp extract, fish emulsion and rock dust to the compost extract increases microbial population growth during the incubation period.

The antifungal effect of pomegranate extract against some phytopathogenic fungi has been studied. Al-Askar (2012) recorded that the extract of pomegranate rinds had antifungal activity against $R$. solani in vitro. Also, the inhibitory effect of Punica granatum against mycelial growth of Botrytis cinerea, Colletotrichum dematium, Fusarium oxysporum, Fusarium solani, Phoma spp, and Rhizoctonia solani was reported by Mohamad, and Khalil (2015). The antimicrobial activity of pomegranate extract is related to attendance of antibiotic compounds such as flavonoids, polyphenols, tannins and anthocyanins (Soma and Prashanth, 2014).

The obtained results revealed that compost teas prepared using alkaline water (using $\mathrm{KOH})$ strongly exhibited more antifungal effect than those prepared using water. Potassium hydroxide has been used to obtain humic extract from composts, and it is the preferred choice as an extracting agent because it produces high humic acid yield and contains high amount of $\mathrm{K}$ (Charest et al., 2005). It was demonstrated that humic substances have molecular characteristics that may result in higher biological activity due to enzymatic activation of nutrient uptake or modification of bacterial cell permeability to nutrients (Tejada et al., 2006).

According to the previous laboratory experiments, a greenhouse experiment was done to prove the efficacy of the tested pomegranate peel powder with compost to control lupine damping-off disease caused by $R$. solani.

Under greenhouse conditions, application of individual compost or combined with pomegranate peel and their extracts effectively decreased pre- and post-emergence damping-off compared to untreated infested control. Significant reduction in disease incidence was observed at pre- and post-emergence stages for pomegranate peel-compost tea treatment.

Some investigators demonstrated that incidence of several soil-borne plant pathogens have been reduced by using composts made of different raw materials (Borrero et al., 2004 \& Abdollahzadeh et al., 2011). Compost tea prepared from vermicompost and shrimp powder was able to increase spinach seedling emergence and reduce pre-emergence damping-off by $R$. solani. 
while, post-emergence damping-off was not affected (Cummings et al., 2009). Greenhouse experiment made by Al-Mughrabi (2007) illustrated that combinations of compost tea and seaweed extract reduced late blight severity of potato.

Aqueous extract of pomegranate peel significantly decreased the incidence of preemergence damping-off and increased the survived lupine plants compared to untreated infested soil (control). Results are in accordance with those reported by Mohamad and Khalil (2015) who found that application of pomegranate peel powder as seed treatment or soil treatment deceased pre- and post-emergence damping-off caused by $F$. oxysporum compared with untreated infected control under greenhouse conditions.

It has been found that plant pathogen inhibition by compost teas is at least partially attributed to the presence of live microorganisms, this suppressive effect may also be attributed to that these teas may confer disease resistance as well as supply essential plant nutrients which improved nutritional status and protect the plant against disease (Al-Mughrabi et al. 2008).

The highest survived plants percentage was achieved with pomegranate peel-compost tea treatment, and this may be due to the positive effect of pomegranate peel on microbial population and activity of compost tea. This result was supported by Scheuerell and Mahaffee (2002) who revealed that additives are added to compost tea to increase microbial population densities during production.

The nodulation status of lupine plants was improved in treated plants compared to untreated control. This may be explained by that organic materials produced a suitable habitat for legume growth and biological nitrogen fixation (Rizk et al., 2011).

The highest values of plant height, shoot and root dry weight, and chlorophyll content of leaves were achieved with pomegranate peel-compost tea. This was in a good accordance with Farzamisepehr et al. (2014) who recorded that compost tea application in pot trial increased fresh weight and dry weight of cress ( Lepidium sativum L.), and the chlorophyll content.

Avis et al. (2008) illustrated that the increasing in growth parameters may be due to the microbial inclusion of compost tea that may promote the growth of the seedling.

The obtained results revealed that pomegranate peel-compost tea could provide a high efficacy to pomegranate peel and compost in combination than that of each individually. Therefore, this combination could be suggested for management of damping-off disease as an 
alternative to fungicides taking in consideration the avoidance of environmental pollution and side effects of pesticide application.

\section{References}

Abd El-Hai, K.M.; El-Metwally, M.A. and Mohamed, N.T. (2016). Hydrogen Peroxide and Acetylsalicylic Acid Induce the Defense of Lupine Against Root Rot Disease. Plant Pathol. J., 15: 17-26.

Abdel-Wahab, A.F.M. (2008). Evaluation of Enriched Compost and its Role in Synergy with Rhizobacteria and N-fertilization for improving Maize Productivity in sandy soil. J. Agric. Sc., 16 (2): 319-334.

Abdollahzadeh, Sh.; Mashouf, RY.; Mortazavi, H.; Moghaddam, M.H.; Roozbahani, N. and Vahedi. M. (2011). Antibacterial and Antifungal Activities of Punica granatum Peel Extracts Against Oral Pathogens. J. of Dentistry, Tehran University of Medical Sciences, Tehran, Iran. 8:1-6

Agarwal, M.; Walia, S.; Dhingra, S.; Khambay, B.P.S. (2001). Insect growth inhibition, antifeedant and antifungal activity of compounds isolated/derived from Zingiber offcinale Roscoe (ginger) rhizomes. Pest Manage. Sci., 57:289-300

Al-Askar A.A. (2012). In vitro antifungal activity of three Saudi plant extracts against some phytopathogenic fungi. J. of Plant Prot. Res., 52(4):458-462.

Al-Mughrabi, K.I. (2007). Suppression of Phytophthora infestans in Potatoes by Foliar Application of Food Nutrients and Compost Tea. Australian J. of Basic and Appl. Sci., 1(4): 785792.

Al-Mughrabi, K.I.; Berthélémé, C.; Livingston, T.; Burgoyne, A.; Poirier, R. and Vikram, A. (2008). Aerobic compost tea, compost and a combination of both reduce the severity of common scab (Streptomyces scabiei) on potato tubers. J. Plant Sci., 3: 168-175.

Arnon, D.I. (1949). Copper Enzymes in Isolated Chloroplasts. Polyphenoloxidase in Beta Vulgaris. Plant Physio., 24: 1-15.

Atlas, R.M. (2010). Handbook of microbiological Media. Fourth edition. CRC Press, Inc., 6000 Broken Sound Parkway NW, Suite 300, Boca Roton, Florida 33487-2742.

Avis, T.J.; Gravel, V.; Antoun, H. and Tweddell, R.J. (2008). Multifaceted beneficial effects of rhizosphere microorganisms on plant health and productivity. Soil Biol. Biochem., 40:17331740 .

Borrero, C.; Trillas, M.I.; Ordova's, J.; Tello, J. and Avile's, M. (2004). Predictive factors for the suppression of Fusarium wilt of tomato in plant growth media. Phytopath., 94:1094-1101.

Charest, H.; Beauchamp, C.J.; Antoun, H. (2005). Effects of the humic substances of deinking paper sludge on the antagonism between two compost bacteria and Pythium ultimum. FEMS Microbio. and Eco., 52:219-227

Cummings, J.A.; Miles, C.A. and Du Toit, L.J. (2009). Greenhouse evaluation of seed and drench treatments for organic management of soilborne pathogens of spinach. Plant Dis. 93: 1281-1292. 
Earp, C.F.; Akingbala, J.O.; Ring, S.H. and Rooney, L.W. (1981). Evaluation of several methods to determine tannins in sorghums with varying kernel characteristics. Cereal chem. 58(3):234-238

Farzamisepehr, M.; Reza, A. and Tafagodinai, B. (2014). Comparison of compost and compost tea effects on Cress (Lepidium sativum L.). Iranian J. of Plant Physio., 4 (3):1029-1037.

Gomez, K. A. and Gomez, A. A. (1984). Statistical Procedures for Agricultural Research. $2^{\text {nd }}$ ed. Wiley-Interscience Publication. New York. 680 pp.

Harborne, J.B. (2005). Phytochemical Methods. New Delhi: Springer (India) Pvt. Ltd. 17.

Hardy, R.W.F.; Burns, R. C. and Holsten (1973). Application of the acetylene-ethylene assay for measurement of nitrogen fixation. Soil Biol. and Biochem., 5: 47-81.

Iglesias-Jimenez, E. and V. Perez-Garcia (1989). Evaluation of city refuse compost maturity: A Review. Biol. Wastes., 27: 115-142.

Ingham, E. R. (2005). The compost tea brewing Manual, Latest Methods and Research. 5th Ed. Soil Food Web Inc., Corvallis, Oregon, USA.

Janisiewicz, W. J.; Conway, W. S.; Glenn, D. M. and Sams, C. E. (1998) "Integrating biological control and calcium treatment for controlling postharvest decay of apples," Hort Sci., 33(1):105-109

Khan, J.A. and Hanee, S. 2011. Antibacterial properties of punica granatum peels. Int. J. Appl. Bio. and Pharma. Tech., 2(3):23-27

Manasi, K.; Ajit, B. and Datar, G. (2014). Antifungal activity of herbal extracts against plant pathogenic fungi. Archives of Phytopath. and Plant Protc., 47(8): 959-965

Mohamad, T.G.M. and Khalil, A.A. (2015). Effect of Agriculture Waste: Pomegranate (Punica granatum L.) Fruits Peel on Some Important Phytopathogenic Fungi and Control of Tomato Damping-off. J. of Appl. Life Sci. Inter., 3(3): 103-113

Mokhtar, M.M. and El-Mougy, N.S. (2014). Bio-compost Application for Controlling Soilborne Plant Pathogens - A Review. Int. J. of Enginee. and Inno. Tech., 4(1): 61-68.

Naidu, Y., Sariah, M., Kadir, J., Siddiqui, Y. (2010). Microbial starter for the enhancement of biological activity of compos tea. Int. J. Agric. Biol. 12: 51-56.

Page, A.L.; Miller, R.H. and Keeney, D.R. (1982). Methods of Soil Analysis.II, Chemical and Microbiological Properties. $2^{\text {nd }}$ ed. Madison Wisconsin. USA

Pare, T.; Gregorich, E. G. and Dinel, H. (1997). Effects of stockpiled and composted manures on germination and initial growth of cress (Lepidium sativum). Bio. Agric. Hort., 14: 1-11.

Rangana S. 1977. Manual of analysis of fruits and vegetables products. Tata Mc Graw Hill Book Company, New Delhi. pp 94-101

Rizk, A. M. A.; Desoky, A. H.; Badawi, F. Sh. F and Morsy, A. R. (2011). Response of two lentil varieties to co-inoculation with Rhizobium and rhizobacteria in calcareous soil. Egypt. J. Appl. Sci., 26: 265-283. 
Scheuerell, S.J. and Mahaffee, W.F. (2002). Compost tea: Principles and prospects for plant disease control. Compost Sci. and Utili., 10(4):313-338.

Scheuerell, S.J. and Mahaffee, W.F. (2006). Variability associated with suppression of gray mold (Botrytis cinerea) on geranium by foliar applications of nonaerated and aerated compost teas. Plant Dis. 90:1201-1208

Singleton, V.L. and Rossi, J.A. (1965): Colorimetry a total phenolics with phosphomolibdicphosphotungstic acid reagents. Am. J. Enol. Vitric. 16, 144-158.

Soma, R. and Prashanth, L. (2014). Solid waste of fruit peels as source of low cost broad spectrum natural antimicrobial compounds furanone, furfural and benezenetriol. Int. J. of Res. in Eng. and Tech., 03(07): 273-279

Tejada, M.; Garcia, C.; Gonzalez, J.L. and Herniandez, M.T. (2006). Use of organic amendment as a strategy for saline soil remediation: influence on the physical, chemical and biological properties of soil. Soil Biol. and Biochem., 38:1413-1421

Whitehead, M.D. (1957). Sorghum, a medium suitable for the increase of inoculum for studies of soil-borne and certain other fungi. Phytopath., 74:450.

$$
\begin{aligned}
& \text { فعالية شاي الكمبوست_قثر الرمان المضادة للفطريات لمكافحة مرض موت البادرات المتسبب عن فطر } \\
& \text { رايزوكتونيا سولاني } \\
& \text { جهى محمد أبو النور 1، زينب محمد حسن خير الله²، عاطف فتح الله عبد الوهاب33، إيهاب علي ضياء محمد سرحان4، منى } \\
& \text { 2، قسم النبات، كلية البنات للآداب و العلوم و التربية، جامعة عين شمس، مصر } \\
& 3 \text { قسم الميكروبيولوجيا الزراعية، معهذ بحوث الأراضي و المباهو البيئة، مركز البحوث الزراعية، الجيزة، مصر } \\
& 4 \text { معهد بحوث امر اض النباتات ، مركز البحوث الزراعية ،الجيزة، مصر } \\
& 5 \text { قسم البيولوجي، كلية العلوم، جامعة الأزهر، غزة، فلسطين }
\end{aligned}
$$


المعاملات التطبيقية أدت الى نقص معنوي في نسبة موت البادرات وأيضا حسنت الحالة العقدية وكذلك معايير النمو مقارنة بالكنترول. كما ان شابي الكمبوست ـقشر الرمان سجل أ على نسبة معنوية لنباتات الترمس الباقية على قيد الحياة وكذللك أعلى معلى معايير نمو يليه المبيد الفطري. ولقد تحققت أحسن حالة عقدية مع المبيد الفطري وشاي الكمبوست ـقشر الرمان. وبالتالي يمكن استتناج ان شاب الكمبوست_قشر الرمان قد يزود الكمبوست وقشر الرمان كفاءة عالية في حالة وجودهما معا ولذلك فانه يمكن استخدامه على النطاق التجاري لمكافحة مرض موت البادر ات. 